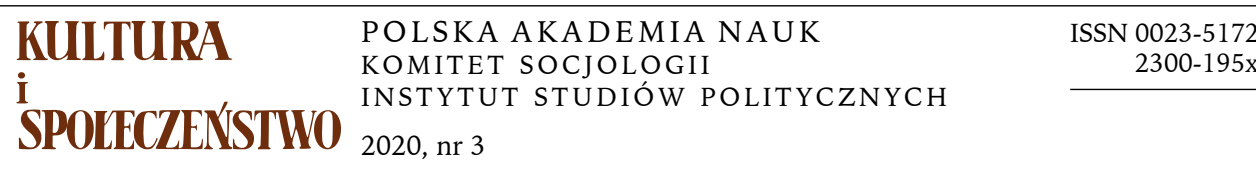

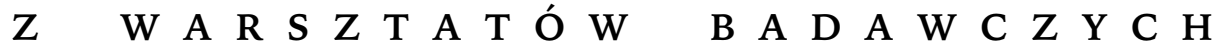

EWA NOWICKA

Collegium Civitas

SŁAWOMIR ŁODZIŃSKI

Uniwersytet Warszawski

\section{ODCIENIE OBCOŚCI}

\author{
WYNIKI SONDAŻU „POLACY I INNI 30 LAT PÓŹNIEJ” - \\ ANALIZA PORÓWNAWCZA $(1988,1998,2018) *$
}

\section{WSTĘP}

Polska z perspektywy badań nad postawami wobec cudzoziemców może stanowić interesujący przypadek. Jest krajem o długich tradycjach migrowania, w którego historii przeplatanie się fal migracji ekonomicznych i politycznych mocno odcisnęło się na kulturze narodowej, a także na społecznościach regionalnych oraz indywidualnych losach wielu pokoleń i rodzin (Zubrzycki 1988). W historii naszej kultury obecne są zarówno tradycje emigracji politycznej, począwszy od okresu rozbiorów i powstań, emigracji zarobkowej sięgającej XIX wieku, jak i przyjmowania imigrantów w roli akceptowanych cudzoziemców. Słowem, Polsce i Polakom nie była i nadal nie jest obca styczność $z$ obcokrajowcami, ani ta w wynikająca $z$ emigracji, ani ta pochodząca $z$ procesów imigracji. Żywy kontakt z cudzoziemcami jest trwałym elementem historii i kultury polskiej i byłoby pewnym nieporozumieniem mówić o „zamkniętości” społeczeństwa pol-

Adres do korespondencji: ewanowickarusek@gmail.com; ORCID: 0000-0003-0170-0845; s.lodzinski@uw.edu.pl; ORCID: 0000-0002-7484-8659

* Artykuł jest zmienioną i poprawioną wersją referatu wygłoszonego w toku XVI Ogólnopolskiego Zjazdu Socjologicznego we Wrocławiu we wrześniu 2019 r. podczas obrad grupy „Heterogeniczność postaw wobec migrantów i mniejszości etnicznych”, zorganizowanej przez Zuzannę Brunarską i Anetę Piekut w ramach Sekcji Socjologii Etniczności PTS. 
skiego tak w przeszłości, jak i obecnie. Tym bardziej zasługuje na uwagę socjologa możliwość badania zmienności i różnorodności postaw wobec cudzoziemców w ich rozmaitych rolach w naszym kraju, w tym zwłaszcza poszukiwanie aksjologicznych reguł rządzących myśleniem o akceptacji bliższych kontaktów z obcymi.

Naszym celem jest analiza wyników sondażu pt. „Polacy i inni po trzydziestu latach", dotyczącego stosunku Polaków do przyjazdu cudzoziemców do naszego kraju, i porównanie ich $z$ rezultatami $z$ analogicznych badań $z$ lat 1988 i 1998, przedstawionych w naszych wcześniejszych opracowaniach (Nowicka 1990; Nowicka, Łodziński 2001). Podstawowym źródłem danych empirycznych, na których oprzemy rozważania, są rezultaty badania zrealizowanego w czerwcu 2018 roku przez firmę Kantar, sfinansowanego w ramach grantu Opus przez Narodowe Centrum Nauki ${ }^{1}$.

Trzy edycje tego samego badania (1988, 1998 i 2018) wykonane były przy użyciu tego samego narzędzia badawczego oraz tej samej metodologii - wywiadów ankieterskich face to face. Jesteśmy przekonani, że mimo różnic kontekstu społecznego (o czym dalej), uzyskane dane porównawcze pozwalają prześledzić z jednej strony długofalowe przeobrażenia wzorów myślenia o swojej tożsamości narodowej (czyli koncepcji polskości), a $z$ drugiej - sposoby funkcjonowania społecznie uznawanych granic etnicznych, zasad inkluzywności i ekskluzywizmu społeczeństwa polskiego, wyrażające się w postawach wobec „innych” - etnicznie i rasowo „obcych", a więc wobec różnych kategorii cudzoziemców.

Wyniki badań z ostatnich trzech dekad pokazują ewolucję zmian postaw wobec cudzoziemców — od życzliwych u progu dekady lat dziewięćdziesiątych ubiegłego wieku poprzez zwiększone poczucie niepewności na przełomie obu wieków, a następnie wzrastającą tolerancję wobec imigrantów (co nastąpiło już w okresie członkostwa Polski w Unii Europejskiej) do pogorszenia tych postaw w sytuacji kryzysu migracyjnego 2015-2018 (Pasamonik, Markowska-Manista 2017; Jaskułowski 2019). Będziemy się też porównawczo odwoływać do wyników badań, które stanowiły część szerszych międzynarodowych projektów badawczych, jak badania porównawcze europejskich wartości (EVS - European Value Study) lub Europejski Sondaż Społeczny (Grzymała-Kazłowska 2012; Andrejuk 2015; Koniecz-

1 Projekt badawczy OPUS 12 pt. „Polacy i inni” trzydzieści lat później realizowany na podstawie umowy UMO-2016/23/B/HS6/03874 z dnia 4 sierpnia 2017 r., zawartej przez Collegium Civitas z Narodowym Centrum Nauki. W skład zespołu badawczego weszli: kierownik Ewa Nowicka, i członkowie zespołu badawczego: Sławomir Łodziński i Maciej Witkowski. 
na-Sałamatin 2019). Wskazywały one na - jak to określali autorzy „umiarkowaną otwartość” wobec migracji i uchodźców.

Nowym impulsem migracyjnym w Polsce stała się integracja $z$ Unią Europejską oraz otworzenie dla migrantów rynków pracy i wynikające $\mathrm{z}$ tego migracje poakcesyjne do Wielkiej Brytanii i Irlandii (Społeczne skutki poakcesyjnych migracji... 2014; Garapich 2019). Mimo że Polska nadal pozostaje krajem emigracji, to kwestie imigracji od połowy 2015 roku, wskutek kryzysu migracyjnego, stały się przedmiotem ożywionej debaty politycznej i społecznej. Wpłynęły one negatywnie na postrzeganie kategorii „uchodźca” oraz na postawy wobec imigrantów (Bielecka-Prus 2018). W tym czasie Polska stała się też docelowym kierunkiem migracji dla osób pochodzących z państw Europy Wschodniej w tym przede wszystkim Ukraińców (w mniejszym stopniu także Białorusinów i Rosjan) (Jaroszewicz 2018). W 2018 roku spośród wszystkich państw członkowskich Organizacji Współpracy Gospodarczej i Rozwoju (skupiającej przecież znaczną większość wysoko rozwiniętych państw), to do Polski przyjechało najwięcej migrantów tymczasowych - więcej niż do Stanów Zjednoczonych, podobnie jak i w 2017 roku (OECD 2019). Dane te świadczą o tym, że imigranci nie są już w Polsce zjawiskiem marginalnym i dziś każdy Polak spotkał lub niebawem spotka jakiegoś cudzoziemca, który nie jest turystą, lecz przyjechał do Polski do pracy albo/i na studia. Ta znacząca zmiana nastąpiła w ciągu ostatnich 7-8 lat (Górny, Kindler 2018). Znaczenie tego problemu zaznacza się $\mathrm{w}$ dyskusji o skutkach zmian demograficznych w naszym kraju, a zwłaszcza trwającego procesu starzenia się społeczeństwa (wynikającego z wydłużania trwania życia ludzkiego i emigracji młodego pokolenia), co wzmaga i będzie wzmagało popyt na pracę cudzoziemców i prowadziło do stosunkowo szybkiego przekształcania Polski $z$ kraju typowo emigracyjnego $\mathrm{w}$ kraj emigracyjno-imigracyjny (Organiściak-Krzykowska 2018, s. 138-143).

W artykule analizujemy wyniki sondażowe dotyczące przede wszystkim nastawień Polaków wobec przyjazdu cudzoziemców do naszego kraju. Stawiamy zarazem hipotezę o wzmaganiu się procesu konkretyzacji obrazu „obcego” w świadomości społeczeństwa polskiego, który staje się także coraz częściej negatywny. Podstawowe pojęcia użyte w artykule to kategorie „swój” i „obcy” oraz „dystans społeczny”, które stanowią część klasycznej tradycji teoretyzowania w socjologii (Wark, Galliher 2007).

Układ artykułu jest następujący, najpierw przedyskutujemy metodologiczne problemy prowadzenia badań wzdłużnych na przykładzie historii przygotowywania i prowadzenia naszych sondaży, następnie przedstawimy wyniki badania dotyczące „otwartości” Polaków na przyjazdy cudzo- 
ziemców oraz uwarunkowania wyrażanych obaw co do możliwych negatywnych skutków wynikających z pojawiania się coraz liczniej w Polsce. Odniesiemy się też do wyrażanej tolerancji na odmienność kulturową, pojawiającą się wraz z obcokrajowcami, czyli podejmiemy temat stosunku badanych do odmiennych obyczajów, które mogą być odbierane nawet jako nieakceptowalne. Kończymy podsumowaniem, w którym zwracamy uwagę na uwarunkowania nastawień wobec cudzoziemców naszym kraju.

Podkreślmy w tym miejscu, że badanie sondażowe "Polacy i inni" nie narzucało badanym definicji cudzoziemca; na odruchowo uruchamiany obraz oraz zespół skojarzeń i opinii wyrażanych podczas badania znaczący wpływ mogły mieć z jednej strony osobiste doświadczenia, a z drugiej — dyskurs publiczny dotyczący migracji, nasilony od 2015 roku. Dodajmy, że słowa "cudzoziemiec” w języku polskim można zamiennie używać z określeniem „obcokrajowiec”, poza tym na terenie Polski jako synonimy mogą wystąpić słowa: „imigrant” lub „uchodźca”. Badanie jakościowe przeprowadzone $\mathrm{w}$ ramach referowanego projektu dotyczyło rozróżniania tych pojęć zarówno wśród młodzieży, jak i osób w wieku emerytalnych „migrant” i „uchodźca” nie zawsze byli rozróżniani i terminologia rzadko była używana ściśle. Cudzoziemcy przebywający na terytorium Polski są grupą zróżnicowaną między innymi ze względu na długość i cel pobytu, a także kraj pochodzenia, sytuację prawną i wreszcie fizjonomię (wygląd zewnętrzny). Ponadto cudzoziemcy w Polsce to grupa głęboko zróżnicowana pod względem zaplecza kulturowego, wyznawanej religii, języka (specyfika rodzimego języka wpływa na wymowę i akcent, gdy cudzoziemiec używa języka polskiego). Zróżnicowany jest też stopień społecznej akceptacji ze strony społeczeństwa polskiego poszczególnych zbiorowości cudzoziemców; sposób postrzegania, w tym stereotypizacji grupy. Ze względu na obcy akcent i niektóre nawyki behawioralne zdarza się też, że cudzoziemcy są odbierani przez Polaków jako polscy obywatele pochodzący z rodzin imigrantów powrotnych lub okresowych. Dzieje się tak z powobu znacznej homogeniczności etnicznej polskiego społeczeństwa.

Dodajmy, że zainteresowanie Polaków problematyką postaw wobec innych narodów i kultur cieszyło się zainteresowaniem. W badaniu z 2018 roku przez zdecydowaną większość badanych poruszane w pytaniach sondażu kwestie zostały uznane za ważne (89\%), zaledwie $7 \%$ respondentów potraktowało je jako nieważne, a jedynie $4 \%$ nie miało zdania. Zatem mamy podstawy sądzić, że stosunek do cudzoziemców, różne typy relacji z nimi to społecznie istotna tematyka. 


\section{METODOLOGICZNE PROBLEMY W PROWADZENIU PORÓWNAWCZYCH BADAŃ WZDŁUŻNYCH}

Prowadzenie analiz porównawczych w długiej perspektywie czasowej (trzydzieści lat głębokich przemian społecznych i politycznych) wymaga zmierzenia się z trudnościami natury metodologicznej. Idealną sytuacją byłoby zachowanie po latach wielu elementów stałych w opisie badanego społeczeństwa, co zbliżałoby do utrzymania w mocy kanonu jedynej różnicy. W wypadku badań społecznych nie jest to z pewnością możliwe, a w badaniu powtarzanym po trzydziestu latach, podczas których dokonały się zmiany rewolucyjne nie tylko na gruncie polskim, ale także w całym świecie, porównania muszą się opierać na spojrzeniu kompleksowym, na studiowaniu zespołów wzajemnie zależnych zmiennych.

Podejmujemy tu problemy związane $z$ długofalowymi badaniami porównawczymi. Najważniejsze kwestie metodologiczne w procesie interpretacji wyników badań powtarzanych po wielu latach dotyczą porównywalności danych uzyskanych w długich odstępach czasu. Kłopoty są efektem całościowych przemian społeczeństwa polskiego. Problem ten pojawił się już wtedy, gdy pisaliśmy książkę U progu otwartego świata (2001), kiedy oba porównywane badania dzieliło zaledwie dziesięć lat. Pisaliśmy wtedy na podstawie wyników sondaży z 1998 roku, że „[...] w latach 90-tych XX wieku migracje grup etnicznych i narodowych oraz obecność cudzoziemców stały się jednym z ważniejszych problemów politycznych i społecznych w wielu krajach, zwłaszcza europejskich. Problemy te nabrały szczególnego charakteru ze względu na swoją masowość i powszechność, dynamikę i złożoność oraz napięcia i konflikty, jakie ze sobą niosą" (Nowicka, Łodziński 2001, s. 7). Już wtedy dyskutowano o problemach grożących Polsce i całej Europie w postaci nasilenia się rasizmu i ksenofobii w wyniku gwałtownego i niekontrolowanego napływu cudzoziemców na Stary Kontynent. Nie zdawaliśmy sobie wówczas sprawy, że zjawiska te nabiorą impetu i po kilkunastu latach wywołają kryzys migracyjny w całej Europie.

Wszystkie trzy sondaże, do których będziemy się porównawczo odwoływali posługiwały się nieomal identycznym w treści i konstrukcji kwestionariuszem pytań, który - w celu utrzymania porównywalności - zachowaliśmy nienaruszony w miarę możliwości. Część elementów wszystkich trzech badań nie uległa zmianie. Dotyczy to brzmienia znakomitej większości pytań, których odpowiedzi nas interesowały w omawianym kontekście. Były to pytania na temat stosunku społeczeństwa polskiego do cudzoziemców (w tym również różniących się fizycznie, o odmiennym kolorze skóry), czyli: 
1) postaw wobec przyjazdów cudzoziemcówdo Polski,

2) preferowanych krajów pochodzenia cudzoziemców przybywających do Polski,

3) obaw o możliwe niekorzystne konsekwencje ich przyjazdów

4) tolerancji na odmienność kulturową osób przybywających (czyli stosunku do ich odmiennych obyczajów, które mogą być odbierane nawet jako nieakceptowalne).

W kwestionariuszu poruszaliśmy także sprawę uogólnionego nastawienia polskich obywateli do możliwości zgodnego życia w jednym kraju ludzi różnych ras i narodów. Scenariusz zawierał także pytania o osobiste doświadczenia respondentów, wynikające $z$ jednej strony ze styczności z cudzoziemcami za granicą (w czasie pracy zarobkowej) i z drugiej strony $z$ zetknięcia się z nimi na terenie naszego kraju, czyli osobistej znajomości cudzoziemców w Polsce.

Jednak pewne drobne zmiany kwestionariusza okazały się niezbędne już w 1998 roku, a po upływie następnych dwudziestu lat byliśmy zmuszeni do wprowadzenia znacznie większej liczby zmian. Dotyczyły one przede wszystkim treści tzw. metryczki, czyli pytań końcowych, pozwalających ulokować w społecznej strukturze osobę respondenta. Metryczkowe pytania $\mathrm{w}$ ostatniej odsłonie z roku 2018 różniły się bardzo od tych, które zastosowano w 1988 roku, co wiązało się z wieloma zmianami społecznymi, instytucjonalnymi i strukturalnymi społeczeństwa polskiego. Niezmienione pozostały pytania dotyczące wieku, płci i miejsca zamieszkania, a zmianie uległy zasadniczo wszystkie inne pytania: dotyczące wykształcenia, zatrudnienia, zawodu, sytuacji materialnej badanego.

Dla przykładu przedstawiamy tylko specyficzne różnice, które pojawiły się w pytaniach i kategoryzacji dotyczącej wykształcenia respondenta. Jedna $z$ istotnych zmian $w$ pytaniach metryczkowych wynika ze struktury systemu edukacji i poziomu wykształcenia. W obecnej próbie losowej znalazły się najstarsze osoby, które kończyły siedmioletnią szkołę podstawową, następnie te, które miały do czynienia z ośmioletnią podstawówką, a następnie te, które po sześcioletniej podstawówce powinny przejść obowiązkowe trzyletnie gimnazjum, a potem szkołę średnią. Na poziomie wykształcenia wyższego obok takich badanych, którzy mają ukończone pięcioletnie studia wyższe, i takich, którzy je tylko częściowo przeszli, zaliczając się do kategorii „nieukończone wyższe”, są i tacy, którzy mają licencjat lub stopień magistra po ukończonym trzyletnim licencjacie oraz dwuletnich studiach drugiego stopnia (magisterskich). Kolejne kategorie poziomu wykształcenia nie mogą więc pokrywać się w badaniach z lat 1988 2018, choć wymagałyby tego cele porównawcze. 
W tym miejscu analiz pojawiają się, mimo zmiany pytań metryczkowych, istotne kłopoty porównawcze. Powstaje pytanie: czy powinniśmy porównywać, wrzucając do jednej kategorii tych, którzy ukończyli siedmioletnią i ośmioletnią szkołę podstawową, z tymi, którzy poprzestali na szóstej klasie szkoły podstawowej razem z tymi, którzy poza sześcioma klasami zaliczyli trzy lata gimnazjum (które w sumie stanowiły do niedawna, i dla ostatnich pozostających $w$ tym systemie jeszcze do dziś stanowią, obowiązujący zakres edukacji podstawowej)? Różnica dwóch lat długości wykształcenia obowiązkowego (siedem i dziewięć lat), a także rozdzielenie do niedawna w obowiązującym systemie klas od pierwszej do szóstej oraz od siódmej do dziewiątej stwarzają kłopot i wzbudzają wątpliwość co do możliwości przeprowadzenia porównania. Rodzi to niepokojące pytania u badacza, który się nastawił na analizę porównawczą i w tej chwili musi się odwołać do rozważań bardziej kompleksowych.

Drugi typ zmian, które wpływają na pewne ograniczenia $\mathrm{w}$ porównywalności trzech sondaży, wiąże się ze zmianami całościowego kontekstu społecznego $-z$ ogromną skalą zmian gospodarczych, politycznych i instytucjonalnych, które nastąpiły $\mathrm{w}$ ciągu trzydziestu lat dzielących pierwsze i ostatnie badanie. Gdy patrzymy z perspektywy trzech dekad, do wszystkich wymienionych dochodzą zmian polityczne, wiążące się ze wstąpieniem Polski do sojuszu wojskowego NATO w roku 1998, a wkrótce, sześć lat później do struktur Unii Europejskiej. Kraje Unii Europejskiej stopniowo otwierały swoje rynki pracy dla imigrantów z Polski, co skutkowało ogromną skalą emigracji z Polski do różnych państw Europy Zachodniej i prowadziło nie tylko do czasowych czy wahadłowych migracji zarobkowych, ale także do odpływu ludności z Polski na stałe. W wyniku emigracji znaczna część społeczeństwa polskiego zetknęła się z odmiennością kulturową i fizyczną ludzi, z którymi mieli się okazję stykać podczas pracy i w życiu codziennym. Inni dzięki możliwości wyjazdów turystycznych zdobyli ogromną wiedzę o różnych „innych”. Dzięki temu dokonały się głębokie zmiany w dyskursie: w języku wypowiedzi, kategoriach myślowych, pojawiły się inne znaczenia znanych terminów, niektóre terminy nabrały negatywnej konotacji, inne odwrotnie - konotacji pozytywnych.

Zauważyć trzeba, że w ciągu trzydziestu lat zmieniła się zasadniczo struktura demograficzna społeczeństwa polskiego, część kohort demograficznych odeszła przekraczając wiek przeżywalności, część „odpłynęła” $\mathrm{w}$ efekcie migracji z kraju (badaniem objęto jedynie osoby zamieszkałe w Polsce), bardzo znaczna część osób objętych badaniem w 2018 roku to osoby młode lub w średnim wieku, które nie mogą pamiętać czasów, gdy przeprowadzane było pierwsze badanie. Zmiany demograficzne doprowa- 
dziły do wzrostu liczby osób starszych, a zmniejszenia się liczby młodych i bardzo młodych, mieszczących się w najmłodszych kategoriach badanej populacji. Nastąpiła naturalna wymiana pokoleń.

Od czasu wykonania pierwszego badania w 1988 roku oprócz zasadniczych przeobrażeń ustrojowych, instytucjonalnych i ekonomicznych w społeczeństwie polskim nastąpiły również poważne zmiany świadomościowe; poszerzył się znacznie zakres wiedzy i refleksji na temat cudzoziemców i ich różnych kategorii. Rozwinęły się postawy i poglądy na tematy kiedyś nieobecne w myśleniu. Stosunek do poszczególnych kategorii cudzoziemców nabrał w naszym kraju konkretnych treści, uległ wyraźnemu zróżnicowaniu. Nie oznacza to jednokierunkowej zmiany postaw ani w stronę bardziej postaw przychylnych, ani w stronę postaw wrogich czy niechętnych.

Trzy terminy przeprowadzenia porównywanych tu badań oznaczaja zatem odmienne wewnętrzne warunki polityczne w Polsce, a także odmienne sytuacje $\mathrm{w}$ zakresie procesów migracyjnych — zarówno emigracji, jak i imigracji. Ostatnia dekada go ponadto czas zetknięcia się polskiej opinii publicznej z przebiegiem i skutkami kryzysu migracyjnego w Europie, w tym ze zjawiskiem terroryzmu i konfliktów, między innymi na tle religijnym. Wszystkie te okoliczności bez wątpienia oddziaływały na kształtowanie się analizowanych tu postaw Polaków wobec cudzoziemców i na formowanie się ich coraz bogatszego w szczegóły i zróżnicowanego wizerunku.

\section{OTWARTOŚĆ POLAKÓW NA PRZYJAZDY CUDZOZIEMCÓW W LATACH 1988-1998-2018}

Analizę rozpoczniemy od odpowiedzi na pytanie dotyczące otwartości wobec przyjazdów cudzoziemców do naszego kraju. Brzmiało ono następująco we wszystkich trzech edycjach naszego badania: „Czy chciał(a)by Pan(i), żeby do Polski częściej przyjeżdżali cudzoziemcy?”. Nie sugerowaliśmy ani charakteru tych przyjazdów, ani określonej długości ich pobytu w Polsce. Badani mogli więc mieć na myśli różnego rodzaju przejawy mobilności: od turystycznej do pracowniczej czy nawet osiedleńczej. Pytanie to miało nam dostarczyć wiedzy o generalnej postawie „otwartości” społeczeństwa polskiego na ruchliwość międzynarodową w otaczającym globalnym świecie. Wyniki różnych badań sugerują, że związana $z$ otwartością możliwość coraz częstszych kontaktów międzyludzkich, zwłaszcza $z$ osobami pochodzącymi z innych regionów kulturowych, i szybsza wymiana informacji może prowadzić do różnych skutków (Bilewicz 2006, 
s. 63-64): albo do stopniowego otwierania się społeczeństwa na globalny świat, zwiększania stopnia tolerancji kulturowej i, w efekcie, postaw przychylnych imigrantom, albo twprost przeciwnie - do wzrostu poczucia zagrożenia i niepewności i w konsekwencji zamykania się na innych przez odrzucanie imigrantów, również tych, którzy już przybbli (Taras 2019, s. 24-29).

Tabela 1

Stosunek do częstszego przyjazdu cudzoziemców do Polski: lata 1988-1998-2018 (w \%)

\begin{tabular}{|l|c|c|c|}
\hline \multirow{2}{*}{ Nastawienie } & \multicolumn{3}{|c|}{ Rok badania } \\
\cline { 2 - 4 } & 1988 & 1998 & 2018 \\
\hline Tak, chciałbym & 25,0 & 29,1 & 11,5 \\
Jest mi to obojętne & 64,1 & 56,1 & 50,0 \\
Nie chciałbym & 6,0 & 11,3 & 31,2 \\
Trudno powiedzieć & 4,9 & 3,5 & 7,3 \\
\hline
\end{tabular}

Źródło: opracowanie własne.

W latach 1988 i 1998 co najmniej jedna czwarta naszych badanych wyraziła zdecydowane poparcie polityki „otwartych drzwi” w kwestii przyjazdów cudzoziemców do Polski" (odpowiednio 25\% i 29,1\%). W 2018 roku odsetek takich reakcji wyraźnie spadł — do poziomu blisko $12 \%$. W odpowiedziach na to pytanie $w$ trzech odsłonach badania dominuje wskazanie na brak zainteresowania tą kwestią i wybór odpowiedzi ,jest mi to obojętne". Jedank o ile takie nastawienie w 1988 roku wybrało blisko dwie trzecie badanych $(64,1 \%$,$) , w 1998$ roku ponad połowa badanych $(56,1 \%)$, o tyle w 2018 roku była to połowa (50\%). Przy czym w ciągu trzydziestu lat dzielących pierwsze i ostatnie badanie istotnej zmianie uległ odsetek postaw negatywnych wobec przyjazdów cudzoziemców — zwiększył się on od 6\% w 1988 roku do ponad 30\% w 2018 roku (a więc ponad pięciokrotnie). Odsetek osób niezdecydowanych, odpowiadających "trudno powiedzieć”, pozostał bez większych zmian (w granicach 3,5-7\%).

Głębszego zainteresowania wymaga, naszym zdaniem, zastanowienie się nad sensem odpowiedzi ,jest to mi obojętne”. Wybór takiej odpowiedzi można traktować zarówno jako formę braku sprzeciwu wobec pojawiania się cudzoziemców w Polsce, w postaci umiarkowanego przyzwolenia, jak i jako słaby wyraz niechęci wobec ich przyjazdów do nas oraz przejaw niekoniecznie życzliwych uczuć wobec nich. Generalnie jednak, gdy połączymy dwa pierwsze typy odpowiedzi, większość badanych Polaków 
nie sprzeciwia się w otwartej formie częstszym wizytom cudzoziemców w naszym kraju. Na przestrzeni trzech kolejnych edycji sondażu widzimy jednak tendencję spadkową deklarowanej otwartości badanych: od 90\% w 1988 roku, do 85\% dekadę później, a w roku 2018 60\%, a mniej o 30 punktów procentowych niż trzydzieści lat wcześniej.

Próbę wyjaśnienia tej znaczącej tendencji należy umieścić w kontekście zmian indywidualnych doświadczeń migracyjnych badanych. Wyniki badania zrealizowanego $\mathrm{w}$ końcu dekady lat osiemdziesiątych ubiegłego wieku mogły wyróżniać się wskazaniem na wysoką otwartość postaw wobec kontaktów z cudzoziemcami, gdyż u podłoża leżały kwestie związane $z$ uprzednią izolacją naszego kraju od świata zewnętrznego. Postawy takie wiązały się z oczekiwaniem zmiany sytuacji politycznej, której częścią miała stać się otwartość naszego kraju na kontakt ze światem. Zbliżona sytuacja mogła być dekadę później, tuż po zmianach ustrojowych roku 1998, którym towarzyszyły wyraźne oczekiwania integracji z państwami Europy Zachodniej. Z kolei w 2018 roku kryzys uchodźczy w Europie zdecydowanie oddziaływał w kierunku powściągliwości wobec bezpośrednich kontaktów z cudzoziemcami. Zatem naszym zdaniem odpowiedzi deklarowane w latach 1988 i 1998 mogły odzwierciedlać postawy związane $z$ oczekiwaniem kontaktu $z$ cudzoziemcami (ich przyjazdów, a nawet osiedlenia się lub pracy w Polsce). Odnosiły się wówczas raczej do zjawiska wyobrażonego niż oglądu realistycznego, oceny skutków rzeczywistych kontaktów. Deklaracje z 2018 roku odzwierciedlają urealnianie opinii i postaw, gdyż kontakt z cudzoziemcami istotnie wzbogacił się, stał się różnorodny, doświadczają go duże części naszego społeczeństwa.

Zbliżone rezultaty otrzymaliśmy $\mathrm{w}$ odpowiedziach na pytanie o stosunek do przyjazdów cudzoziemców o innym kolorze skóry („A gdyby to byli cudzoziemcy o innym kolorze skóry, to czy chciał(a)by Pan(i), aby częściej przyjeżdżali oni do Polski?" (tabela 2).

O ile w latach 1988 i 1998 co szósty badany (16-17\%) popierał takie przyjazdy, to w 2018 roku odpowiedni odsetek spadł do poziomu blisko $8 \%$. We wszystkich analizowanych latach omawiane odsetki te są mniejsze od tych, które dotyczą generalnego nastawienia wobec przyjazdu cudzoziemców (w latach 1988 i 1998 o 9-13 punktów procentowych, a w 2018 r. o niecałe 4). Oznacza to, że dla pewnej części naszych badanych otwartych na wizyty cudzoziemców kwestia koloru skóry imigranta ma znaczenie, co może sugerować dystans wobec tej kategorii osób (Nowicka 2011, s. 125-129; Switat 2018, s. 201-209).

Trzeba jednak podkreślić, że w kwestii liczniejszego pojawienia się osób o innym kolorze skóry dominuje postawa „obojętności”, którą w la- 
Tabela 2

Stosunek do częstszego przyjazdu do Polski cudzoziemców o innym kolorze skóry: lata 1988-1998-2018 (w \%)

\begin{tabular}{|l|c|c|c|}
\hline \multirow{2}{*}{ Nastawienie } & \multicolumn{3}{|c|}{ Rok badania } \\
\cline { 2 - 4 } & 1988 & 1998 & 2018 \\
\hline Tak, chciałbym & 17,0 & 16,2 & 7,9 \\
Jest mi to obojętne & 68,0 & 67,2 & 58,5 \\
Nie chciałbym & 11,0 & 12,8 & 28,5 \\
Trudno powiedzieć & 4,0 & 3,8 & 5,1 \\
\hline
\end{tabular}

Źródło: opracowanie własne.

tach 1988 i 1998 wskazało blisko dwie trzecie badanych (odpowiednio $68,0 \%$ i $67,2 \%$ ), a 2018 roku odsetek był tylko trochę tylko trochę niższy - $(58,5 \%)$. Odsetek respondentów przeciwnych ich przyjazdom w latach 1988 i 1998 był na zbliżonym poziomie (11-12,8\%), a w 2018 roku wzrósł ponad dwukrotnie, do poziomu prawie $30 \%$ (28,5\%). W poprzednich edycjach badania (lata 1988 i 1998) ten odsetek był wyższy niż odsetek badanych generalnie przeciwnych przyjazdom cudzoziemców do naszego kraju. W 2018 roku są one już prawie wyrównane, a dokładniej różnią się o 3 punkty procentowe (a więc w granicach błędu statystycznego).

Porównanie wyników badań sugeruje, że w kwestii otwartości na przyjazdy cudzoziemców o innym kolorze skóry pojawia się tendencja spadku poparcia i obojętności wobec ich przyjazdów na rzecz wzrostu sprzeciwu wobec nich, a jednocześnie rezultaty z 2018 roku mówią o tym, że kolor lub pochodzenie rasowe może dla badanych odgrywać mniejsze znaczenie. O ile w 1988 roku dla przeciętnego Polaka przedstawicielem cudzoziemca o innym kolorze skóry zazwyczaj był student zagraniczny z Afryki, Azji czy Ameryki Łacińskiej, to obecnie może to być standardowo zarówno uchodźca poszukujący pomocy, jaki i migrant z wielkiej fali migracyjnej po 2015 roku. Ewentualnie, jak trzydzieści lat temu, może to być też student zagraniczny lub osoba pracująca w Polsce na umowie.

Zwróćmy teraz uwagę na zróżnicowanie społeczno-demograficzne otrzymanych w 2018 roku wyników i przyjrzyjmy się, jak badane postawy różnią się w poszczególnych kategoriach społecznych. Najbardziej przeciwne przyjazdom cudzoziemców były osoby o najniższym, podstawowym wykształceniu (44\%, w przypadku respondentów z wyższym wykształceniem ten odsetek wyniósł 20 punktów procentowych mniej), będące na emeryturze $(39 \%)$ lub na rencie $(30,8 \%)$, zajmujące się domem $(30,6 \%)$. 
Częściej taki sprzeciw wyrażały też osoby wierzące i praktykujące (36\%), a także wyborcy partii Kukiz'15 (45\%) i PiS (43\%).

Z kolei najbardziej popierającymi politykę otwartych drzwi najczęściej były osoby $z$ wyższym wykształceniem (13\%, a przypadku respondentów o podstawowym wykształceniu ten odsetek wyniósł 6\%), pracujące na samozatrudnieniu i prowadzące własną firmę (25-26\%), w tych obydwu przypadkach co czwarty badany wyraził chęć częstszych przyjazdów cudzoziemców, osoby deklarujące się jako niewierzące (65\%) oraz wierzące, ale nieregularnie praktykujące $(64,1 \%)$ oraz respondenci reprezentujący elektorat partii „Nowoczesna” i „Razem” (blisko co czwarty badany wyrażał zdecydowane poparcie dla częstszych przyjazdów cudzoziemców).

Podobne zależności były widoczne w wypadku otwartości wobec przyjazdu osób odmiennych rasowo, choć nie były one tak wyraźne. Dodajmy, że na uwagę zasługuje związek między wykształceniem a obojętnym nastawieniem wobec przyjazdu cudzoziemców do Polski, polegający na tym, że im wyższe wykształcenie badanego, tym względnie częściej wyrażał on właśnie taką postawę. Tę prawidłowość możemy interpretować jako wynik większego indywidualizmu osób dobrze wykształconych oraz specyficznej „obojętności”, która może polegać na uznaniu za oczywistość powszechnego przemieszczania się obecnie ludzi w świecie.

Widoczne były także różnice regionalne (wojewódzkie). Stosunkowo najrzadziej wobec przyjazdu cudzoziemców byli przychylni mieszkańcy województw podkarpackiego (51,7\% odpowiedzi „Nie chciał(a)bym”), następnie lubelskiego $(41,4 \%)$, mazowieckiego $(38,6 \%)$ oraz łódzkiego, śląskiego, wielkopolskiego i kujawsko-pomorskiego (na podobnym poziomie ok. 34\%). Z kolei stosunkowo najbardziej przychylni byli badani pochodzący z województw opolskiego i świętokrzyskiego (co czwarty badany wyrażał chęć częstszych przyjazdów obcokrajowców). Wyniki te są zbliżone do uzyskanych w sondażu CBOS (2017, s. 5), według którego stosunkowo najmniej przychylni wobec uchodźców byli mieszkańcy województw łódzkiego i podkarpackiego (60\% przeciwników przyjmowania uchodźców) oraz lubelskiego i opolskiego (podobnie po 58\%). Z kolei stosunkowo najczęściej przychylni byli badani pochodzący z województw dolnośląskiego, mazowieckiego, pomorskiego i zachodniopomorskiego (po 49\% przeciwników przyjmowania uchodźców).

Na podstawie zgromadzonych danych ilościowych można stwierdzić, że społeczno-demograficzne cechy respondenta mają związek statystyczny z jego otwartością na imigrację. Na szczególną uwagę zasługują takie zmienne różnicujące, jak wykształcenie i praktyki religijne, gdyż istnieje 
związek statystyczny między tymi zmiennymi a analizowanymi postawami. Dodajmy też, że zbliżony wzór zróżnicowania społeczno-demograficznego zaznaczył się zarówno w 1988, jak i w 1998 roku. Wykształcenie respondentów nadal odgrywa najważniejszą rolę (im wyższe, tym częściej deklarowana jest otwartość). W 2018 roku pojawiają się nowe związki przede wszystkim rola poglądów politycznych, które mogą utwierdzać indywidualne przekonania badanych oraz rola deklarowanego stopnia i typu religijności. Oczywiście trzeba pamiętać, że sondaż w 1988 roku nie mógł rzetelnie uwzględnić ani poglądów politycznych, ani przekonań światopoglądowych.

Ogólnie możemy powierzieć, że w 2018 roku zauważalny jest — w porównaniu deklaracjami respondentów w odpowiedzi analogiczne pytania adane w poprzednich edycjach badania (lata 1988 i 1998) - wyraźny spadek odsetka postaw niesprzeciwiania się częstszym przyjazdom cudzoziemców do Polski na rzecz wzrostu odsetka osób wyraźnie im przeciwnych. Należy pamiętać zarówno o roli osobistych doświadczeń, które przez lata przybrały postać rzeczywistej, już z nie tylko abstrakcyjnej, styczności z cudzoziemcami, jak i o oddziaływaniu dyskursu medialnego, który powstał wokół kryzysu migracyjnego (Bielecka-Prus 2018, s. 28-29).

Jako dowód na oddziaływnie tych czynników możemy przywołać sondaż CBOS przeprowadzony wiosną 2015 roku, tuż przed wybuchem kryzysu migracyjnego. W odpowiedzi na pytanie: „Proszę powiedzieć, czy zgadza się Pan(i), czy też nie zgadza z poniższym stwierdzeniem: dla wszystkich państw jest korzystne, jeśli ludzie mogą przemieszczać się do innych państw, aby tam pracować?" większość badanych (68\%) zgodziła się z zawartą w nim opinią, a tylko co dziewiąty badany (11\%) ją odrzucił. Zauważyć trzeba, że $\mathrm{w}$ tak sformułowanym pytaniu pojawiali się przybysze $z$ innych krajów przybywający „aby pracować”, co zasadniczo zawęża, w porównaniu z naszym badaniem, kategorię, do której badani mieli się odnieść. Większość badanych w tym samym sondażu (66\%) odpowiedziała pozytywnie na pytanie „Proszę powiedzieć, czy zgadza się Pan(i), czy też nie zgadza $z$ poniższym stwierdzeniem - obecność cudzoziemców wzbogaca różnorodność kulturową i sprawia, że ludzie są bardziej otwarci na innych?". Pozostałe odpowiedzi: 13\% — stosunek negatywny, 15\% odpowiedź neutralna („ani się zgadzam, ani nie zgadzam”), 6\% - „trudno powiedzieć". Pozytywną opinię deklarowali lepiej wykształceni badani, osoby o poglądach lewicowych oraz mieszkańcy dużych miast (powyżej 100 tys. mieszkańców), a rzadziej najstarsi respondenci w wieku powyżej 55 lat (CBOS 2015, s. 1-2). 


\section{OBECNOŚĆ CUDZOZIEMCÓW W POLSCE — ZAGROŻENIA}

W badaniu skoncentrowaliśmy się też na bardziej szczegółowym aspekcie stosunku do przyjmowania w naszym kraju cudzoziemców, jakim jest dostrzeganie imigrantach źródła zagrożeń (Croucher 2016). Pytanie brzmiało dość ogólnie: „Czy obecność cudzoziemców w Polsce może powodować coś złego?” (tabela 3).

Tabela 3

Czy obecność cudzoziemców Polsce może powodować coś złego? (w \%)

\begin{tabular}{|l|c|c|c|}
\hline \multirow{2}{*}{ Odpowiedzi } & \multicolumn{3}{|c|}{ Lata } \\
\cline { 2 - 4 } & 1988 & 1998 & 2018 \\
\hline Tak & 15,0 & 36,1 & 37,6 \\
Nie & 66,0 & 52,8 & 33,9 \\
Trudno powiedzieć & 19,0 & 11,1 & 28,5 \\
\hline
\end{tabular}

Źródło: opracowanie własne.

O ile w 1988 roku co siódmy badany (15\%) zgadzał się z opinią, że cudzoziemcy mogą by źródłem negatywnych zjawisk, dwie trzecie (66\%) było przeciwnego zdania, a blisko co piąty respondent nie miał wyrobionego zdania (19\%), to po dziesięciu latach wyniki uległy zmianie ponad jedna trzecia badanych $(36,1 \%)$ postrzegała, że przybysze mogą stawać się źródłem zagrożeń, a nie zgadzał się z tą opinią co drugi respondent $(52,8 \%)$, co dziesiąty udzielił odpowiedzi „trudno powiedzieć” - 11,1\%. W 2018 roku obraz ten po raz kolejny się zmienił. Podobnie jak w roku1998 ponad dwie trzecie badanych uważało, że cudzoziemcy mogą być dla nas źródłem zagrożeń, ale jedna trzecia była zdania przeciwnego $(33,9 \%)$, natomiast ponad jedna czwarta badanych $(28,5 \%)$ nie miała w tej sprawie zdania. Te trzy badania - w latach 1988, 1998 i 2018 dostarczają dobrego wglądu $\mathrm{w}$ zmianę społecznego postrzegania sytuacji migracyjnej i obecności cudzoziemców w Polsce przez ostatnie trzy dekady (Konieczna-Sałamatin 2019, s. 71-73).

W 2018 roku zagrożenia związane z pobytem cudzoziemców w Polsce najczęściej deklarowali mężczyźni ( $42 \%$ wobec $34 \%$ kobiet), osoby o najniższym podstawowym wykształceniu (51\%), będące na rencie $(58 \%)$ lub niepracujące $(46,0 \%)$, osoby wierzące i systematycznie praktykujące $(42 \%)$ oraz wyborcy partii PIS i Kukiz' 15 (odpowiednio 53\% i 51\%). Natomiast kategorie społeczne, w których częśniej niż w innych katego- 
riach społecznych pojawiało się przekonanie, że obecność w Polsce cudzoziemców nie jest źródłem niebezpiecznych zjawisk, to kobiety (37\% wobec $31 \%$ wśród mężczyzn), osoby z wykształceniem średnim i wyższym (34\% i 40\%), prowadzące własną działalność gospodarczą (57\%) i samozatrudnione (38\%), deklarujące się jako niewierzące $(40 \%)$ i wierzące i nieregularnie praktykujące $(37 \%)$ oraz członkowie elektoratów partii Korwina-Mikkego Wolność (57\%), Platformy Obywatelskiej (51\%) i Nowoczesnej (48\%).

Ten układ zróżnicowania społeczno-demograficznego był zbliżony do tego, który pojawił się w wypadku odpowiedzi na pytanie dotyczące poparcia przyjazdu cudzoziemców do Polski. Jednak porówując wyniki z 2018 roku z rezultatami odpowiedzi na to pytanie z poprzednich edycji, można zauważyć, że z jednej strony liczy się kategoria płci, która wcześniej nie odgrywała żadnej roli, a $z$ drugiej prawie żadnej roli różnicującej nie odgrywa wieku (w 1998 roku najczęściej wskazywali na zagrożenia młodzi ludzie w wieku 15-19 lat oraz najstarsi badani, powyżej 60 roku życia).

Zamierzaliśmy również dotrzeć do głębszych warstw poglądów na temat zagrożeń, które mogą przynosić cudzoziemcy (tabela 4). Prosiliśmy badanych o wskazanie tych konkretnych zagrożeń, które przychodzą im do głowy. Dało to dobry wgląd w zmianę społecznej percepcji sytuacji migracyjnej naszego kraju.

Jak widać, wymieniano przede wszystkim (36\%) zagrożenia dla bezpieczeństwa poszczególnych obywateli w miejscach publicznych, które mogą stać się sceną zamachów terrorystycznych. Mogą też doprowadzić do przeniesienia konfliktów wojennych/niepokoju na grunt całego kraju i państwa jako całości (odpowiedzi typu: zamęt $i$ brak równowagi na ulicach; zamachy terrorystyczne jak przyjada muzułamany; mordy, zjawiska terrorystyczne, zamachy; wojny domowe; wojna). Taki sam był odsetek wypowiedzi dotyczących wzrostu pospolitej przestępczości (odpowiedzi typu: wzrośnie przestępczość; kradzieże, grabieże; zwiększona ilość napadów i kradzieży; masowe wymierzanie swojej sprawiedliwości; rasizm; dochodzi do przemocy na tle rasowym, zatargów między grupami szczególnie młodych ludzi na tle rasowym i koloru skóry; różne zachowania na tle rasowym oraz złe traktowanie na przykład kobiet, gwatcenie kobiet; brak szacunku dla drugiej osoby zwłaszcza dla kobiet; molestowanie; brak poszanowania dla kobiet; gwatty).

W tę perspektywę wpisuje się kategoria odpowiedzi związanych ze spodziewanym wzrostem niepokojów społecznych (24\%) i w ich wyniku utratą kontroli nad społeczeństwem (demonstracje; nieznajomość polskiego prawa może prowadzić do tamania go; brak znajomości języka polskiego; gettoizacja, że będa jakieś dzielnice, gdzie Polacy boją się wchodzić; wykluczenie społeczne; 
Tabela 4

Rozdaje zagrożeń powodowanych przez cudzoziemców w Polsce w opinii badanych w 2018 roku (w \%)

\begin{tabular}{|l|c|}
\hline \multicolumn{1}{|c|}{ Rozdaje zagrożeń } & Procent \\
\hline $\begin{array}{l}\text { Zagrożenie w miejscach publicznych (zamachy terrorystyczne, konflikty wojenne, } \\
\text { mordy) }\end{array}$ & 36 \\
$\begin{array}{l}\text { Wzrost przestępczości (zwiększona liczba napadów, kradzieży, zwiększona liczba } \\
\text { aktów rasizmu i przemocy wobec kobiet) }\end{array}$ & 36 \\
$\begin{array}{l}\text { Wzrost niepokojów społecznych (utrata kontroli nad społeczeństwem, problemy } \\
\text { integracyjne związane z imigrantami) }\end{array}$ & 24 \\
$\begin{array}{l}\text { Chaos kulturowy (zmiany kulturowe w Polsce, narzucanie innej religii, rozbicie } \\
\text { jedności narodowej) }\end{array}$ & 23 \\
$\begin{array}{l}\text { Trudności gospodarcze (zabieranie miejsc pracy, obciążenia finansowe dla pań- } \\
\text { stwa) }\end{array}$ & 12 \\
$\begin{array}{l}\text { Podobne problemy jak w krajach Europy Zachodniej } \\
\text { Inne }\end{array}$ & 4 \\
\hline
\end{tabular}

Źródło: opracowanie własne. Odpowiedzi nie sumują się do 100\%, gdyż badani mogli wskazywać na więcej niż jeden typ zagrożenia. Byli to tylko, ci którzy udzielili odpowiedzi twierdzącej na pytanie o istnienie zagrożenia.

frustracja; nierówności społeczne). Obawy dotyczyły też rozwoju sytuacji społecznej w kierunku, który znamy z krajów Europy Zachodniej. Badani wskazywali również na możliwość zaistnienia w naszym kraju chaosu kulturowego (23\%), który miał polegać między innymi na zmianach kulturowych, co oznaczało ogólną negatywną ocenę i odrzucenie obcych wzorów kulturowych, które na różne sposoby mogą zaszkodzić społeczeństwu polskiemu (odpowiedzi typu: złe nawyki i obyczaje; zła narodowość; zła kultura; zły wpływ na polska kulturę). Pojawiała się obawa przed próbami narzucania swojej religii przez cudzoziemców (odpowiedzi typu: narzucanie wyznania; narzucanie swojej religii; fanatyzm religijny; niszczenie wiary; niezrozumienie naszej religii; na tle religijnym). Zarysowała się też troska o rozbicie spójności narodowej (odpowiedzi typu: rozbicie jedności narodowej; niespójność narodu; multikulti; moga zaczaćc wynaradawiać kraj; po pewnym czasie nie byłoby Polski). Zestaw uzyskanych odpowiedzi wskazuje na zakres zasadniczych wartości, odbieranych jako wyjątkowo ważne i narażone na zagrożenia $z$ zewnątrz. Są to: uregulowane życie według tradycyjnych wartości, czasem związanych z wyznawaną religią, czasem ze spokojem rodzinnym.

Godne odnotowania jest to, że zagrożenia dla naszego kraju ze strony przybywających cudzoziemców związane z kwestiami gospodarczymi 
pojawiają się znacznie rzadziej. Można powiedzieć, że cudzoziemcy rzadziej są odbierani jako groźni dla Polski jako całości. Wyobrażone zagrożenia $(12 \%)$ polegały na wpływie na rynek pracy i obniżaniu wysokości płac (odpowiedzi typu: zmniejszanie miejsc pracy dla nas; zaniżenie płac; zajmuja miejsca pracy; zachwianie rynku pracy). Zapewne ten cudzoziemiec, którego spodziewali się respondenci w Polsce, to nie zawsze miał być pracownik zabierający pracę. Mógł by to być też cudzoziemiec, do którego bardziej pasuje określenie „uchodźca”, który niczego dobrego nie przynosząc Polsce, jedynie obciąży wydatki państwa polskiego. Przykładowe odpowiedzi brzmiały: będzie trzeba ich utrzymywać; roszczeniowośc; wykorzystywanie naszej dobroci i gościnności; korzystanie z opieki społecznej lub wystapitby problem mieszkaniow. W tym kontekście pojawiły się również odpowiedzi wskazujące na podobne zjawiska wystepujące w innych krajach Europy Zachodniej (4\%). Jako „inne” (6\%) zostały zostały zaklasyfikowane pojedyncze odpowiedzi typu: przynosza nieznane nam choroby; zabieranie dzieci; za dużo ich jak będzie to będa nami rządzić; będa chcieli rządzić Polska matymi krokami).

Typy wskazywanych przez badanych zagrożeń wynikających z ewentualnego przyjazdu do nas cudzoziemców są związane przede wszystkim z poczuciem zagrożenia bezpieczeństwa, zarówno kraju, jak i osobistego, przekonaniem o wykorzystywaniu przez nich wsparcia socjalnego oraz zagrożeniem dla kultury polskiej (przede wszystkim przez islam). Wśród innych powodów zaniepokojenia badani wymieniali sytuację na krajowym rynku pracy i wspominali o finansowaniu pomocy z „moich” podatków (Andrejuk 2017, s. 116-125). W dużym stopniu za taki obraz zagrożeń jest odpowiedzialny dyskurs medialny trwający za sprawą przekazów związanych z zamachami terrorystycznymi, które kojarzone są z falą uchodźców pochodzących z krajów arabskich (Pędziwiatr 2015, s. 139). Na poziomie politycznym obawy te przerodziły się $\mathrm{w}$ postulat dążenia do pełnej ochrony mieszkańców Polski i zapewnienia im bezpieczeństwa, a polityka wobec przyjazdu cudzoziemców stała się elementem szerszej strategii państwa, w której niewiele miejsca pozostawiano już na dyskusję o ich prawach i możliwościach ich integracji w naszym społeczeństwie (Bauman 2016, s. 31-54). Znalazło to wyraz w badaniu przeprowadzonym w kwietnia 2017 roku przez firmę Kantar Public, w którym zamachy terrorystyczne oraz obawy związane $z$ napływem uchodźców zostały uznane za te największe stojące przed Polakami zagrożenia (odpowiednio 38\% i 37\%) (Cieśla 2017). Są to wyniki bardzo zbliżone do tych, które uzyskano w 2016 roku w pogłębionym badaniu młodych Polaków (w wieku 18-30 lat) (Hall, Mikulska-Jolles 2016, s. 62-76). 
Nasza analiza zagrożeń związanych z obecnością cudzoziemców w Polsce $\mathrm{w}$ trzech ostatnich dekadach pokazuje nie tylko różnice w wynikach wskazań poszczególne kategorie odpowiedziach na powtarzające się w badaniach pytania, ale przede wszystkim pozwala wydobyć zmianę ich treści. W 1988 roku dominującym wskazaniem $(37,8 \%)$ były odpowiedzi mówiące o zagrożeniach politycznych, w których cudzoziemiec był postrzegany w roli szpiega, sabotażysty niszczącego podstawy polskiej państwowości), oraz kulturowych $(26,3 \%)$, w których był on widziany jako osoba prowadząca do rozkładu polskich obyczajów w postaci wielożeństwa i demoralizacji seksualnej lub życia na pokaz. Kwestie zagrożeń o charakterze gospodarczym lub związanym bezpieczeństwem porządku publicznego (,agresywne zachowanie cudzoziemców”) były rzadko wspominane (odpowiednio po $5,2 \%$ wskazań).

Charakter przewidywanych zagrożeń ze strony cudzoziemców zmienił się już w 1998 roku. Obcość kulturowa (etniczna, religijna) lub odmienność rasowa nie stanowiły kwestii kluczowej, istotne były natomiast cele przyjazdów cudzoziemców do Polski oraz charakter ich pobytów. W postrzeganiu migrantów najważniejsze były wówczas obawy związane z przestępczością (57,1\% wypowiedzi), typu rozboje. Zagrożenie gospodarcze było wymieniało w 25,2\% badanych, a kulturowe 13,5\%. Wyniki trzeba umieścić w kontekście życia społecznego drugiej połowie lat dziewięćdziesiątych, gdy nieuporządkowaniu wielu sfer życia ekonomicznego w Polsce towarzyszyła przestępczość gospodarcza na małą i wielką skalę, a nawet mafijność i często niejasność reguł gry w życiu gospodarczym.

Wart podkreślenia jest niewielki udział ekonomicznych i politycznych domniemanych zagrożeń $\mathrm{w}$ myśleniu respondentów o cudzoziemcach w badaniu z 2018 roku. Były one bardzo widoczne w badaniach wcześniejszych. Różnicę tę trzeba umieścić w kontekście szeroko zakrojonych zmian ustrojowych, a także treści dyskursu publicznego po przełomie politycznym 1989 roku. Istotne jest też, kim był „cudzoziemiec” dla naszych respondentów w poszczególnych latach zestawianych tu badań. Niewątpliwie inny obraz cudzoziemca mieli Polacy w końcowym okresie władzy komunistycznej, inny w początkowym, niespokojnym, niejasnym, ekonomicznie trudnym i społecznie/politycznie skomplikowanym okresie wczesnych przemian ekonomicznych i ustrojowych, który był przełomowym czasem nadziei, rozczarowań i konstruktywnej działalności.

W 2018 roku cudzoziemiec przybywający do Polski stał się kim innym. Pojawiły się role, o których nie myślano wcześniej (Winiarska, Wojno 2018, s. 345-348). Gdy Polska zasiliła rynek pracy Europy Zachodniej, powstały $\mathrm{w}$ naszym kraju niedobory rąk do pracy — fala przybyszów 
ze wschodu zaczęła pełnić pozytywną rolę. Zresztą w dawniejszych czasach obcokrajowcy pracujący $\mathrm{w}$ przemyśle i na roli byli społeczeństwu polskiemu dobrze znani i większość tego typu kontaktów zamknęła dopiero socjalistyczna Polska. Potwierdzenie wagi obecności cudzoziemców w naszym kraju można odnaleźć w przeprowadzonym podczas kampanii samorządowej jesienią 2018 roku przez Helsińską Fundację Praw Człowieka monitoringu, który wykazał, że częste kontakty z pracującymi w Polsce migrantami powodują dostrzeganie korzyści z ich obecności w Polsce (Migranci, uchodźcy i... 2018, s. 33-34).

\section{CUDZOZIEMCY PREFEROWANI W POLSCE}

Interesujące wyniki przynoszą odpowiedzi na pytanie o kraje pochodzenia (grupy narodowe) cudzoziemców najbardziej popieranych przez badanych w roli przybyszów. Brzmiało ono następująco: „Proszę uzupełnić podane poniżej zdania, wpisując do każdego z nich trzy nazwy krajów: 1. chciał(a)bym, aby do Polski przyjeżdżali cudzoziemcy z następujących krajów: ...".

W 1998 roku najchętniej witani w naszym kraju cudzoziemcy to: obywatele Niemiec, USA, Francji, Wielkiej Brytanii oraz innych krajów Europy Zachodniej. Na siódmej/ósmej pozycji znaleźli się obywatele Czech na równi z obywatelami Holandii. Polacy popierali więc przyjazdy do Polski cudzoziemców z krajów bogatych i rozwiniętych, państw określanych mianem „Zachodu”. Podobne wyniki otrzymaliśmy w 2018 roku — dominowała wówczas otwartość wobec przyjazdu obywateli Wielkiej Brytanii (Anglii) oraz Niemiec, na których wskazywała jedna trzecia badanych, a następnie obywateli Włoch i USA (blisko jedna piąta wskazań) oraz Francji i Hiszpanii (jedna szósta wskazań). Nowym (w ogóle nie wskazywanym w 1998 r.) pożądanym krajem stała się Ukraina, którą wskazała jedna siódma wypowiadających się respondentów. W 2018 roku można było zaobserwować zmniejszenie się odsetka badanych, którzy wybierali odpowiedź „ze wszystkich krajów” (3,2\% wobec 7,9\% w 1998 r.). Preferowanie cudzoziemców z określonych krajów wskazuje na wyższy poziom konkretyzacji obcego - wzrost świadomości różnic — stąd zróżnicowany pożądany kontakt $z$ osobami z obszarów bezpiecznych, zamożnych, kojarzących się z krajami, z których nie płynie żadne istotne zagrożenie.

Jest to częściowo jest zgodne $z$ wynikami sondażu CBOS (2018a) na temat postrzegania innych narodów przez Polaków. Według niego największą sympatią respondenci darzyli Czechów, Włochów, Amerykanów, Anglików, Słowaków oraz Węgrów (do których pozytywny stosunek de- 
Tabela 5

Kraje pochodzenia cudzoziemców najchętniej witanych w Polsce: lata 1998-2018 (w \%)

\begin{tabular}{|l|r|l|r|}
\hline \multicolumn{2}{|c|}{1998} & \multicolumn{2}{|c|}{2018} \\
\hline Niemcy & 40,3 & Anglia (Anglicy, Wielka Brytania) & 35,5 \\
FSA (Ameryka) & 37,9 & Niemcy & 32,2 \\
Wielka Brytania & 36,1 & Włochy (Włosi) & 22,3 \\
Włochy & 30,6 & USA (Amerykanie) & 19,4 \\
Kraje skandynawskie & 17,4 & Francja (Francuzi) & 17,9 \\
Holandia & 9,4 & Hiszpania & 14,9 \\
Czechy & 5,6 & Ukraina & 12,8 \\
Japonia & 5,6 & Czechy (Czesi) & 11,0 \\
Hiszpania & 4,8 & Holandia (Holendrzy) & 8,4 \\
Rosja & 4,0 & Szwecja & 6,6 \\
Kanada & 3,0 & Węgry & 6,1 \\
Austria & 2,9 & Chiny (Chińczycy) & 5,5 \\
Szwajcaria & 2,7 & Słowacja & 4,8 \\
Słowacja & 2,6 & Grecja & 4,4 \\
ze wszystkich krajów & 1,7 & Norwegia & 4,2 \\
trudno powiedzieć & 7,9 & ze wszystkich krajów & 3,2 \\
\hline
\end{tabular}

Źródło: opracowanie własne. Odpowiedzi nie sumują się do 100\%, gdyż badani mogli wskazywać trzy kraje. Pytania nie zadano w badaniu z 1988 roku.

klarowało ponad dwie piąte ankietowanych, od $42 \%$ do $44 \%$ ), niewiele mniej respondentów - ponad jedna trzecia - z sympatią odnosiło się do Hiszpanów, Norwegów, Greków i Szwedów (od 34\% do 40\%). Co trzeci badany miał pozytywne nastawienie do Japończyków i Francuzów (po $33 \%$ ). Należy zaznaczyć, że w stosunku do Niemców poglądy były równo podzielone: trzech na dziesięciu ankietowanych (30\%) zadeklarowało pozytywne nastawienie, a negatywne - ponad jedna trzecia (36\%). Mniejsza grupa respondentów wyrażała sympatię do Ukraińców (24\%), a przeważała niechęć wobec nich (40\% wskazań) (CBOS 2018a, s. 1-3). Porównanie wyników obu badań wymaga odnotowania, że my pytaliśmy expressis verbis o przyjazdy do Polski cudzoziemców, a w sondażu CBOS była to uogólniona sympatia.

Możemy powiedzieć, że wyniki z lat 1998 i 2018 wskazują, iż Polacy popierają politykę otwartych drzwi przede wszystkim wobec cudzoziem- 
ców pochodzących z krajów bogatych i rozwiniętych, a są mniej otwarci na przedstawicieli krajów biednych oraz przybyszy z terenów byłego ZSRR (z wyjątkiem Ukrainy). Choć postawy zdecydowanie restryktywne wobec przyjazdów do Polski nie znajdują dużego odzwierciedlenia w opiniach badanych, to ujawnienie się mniej otwartych nastawień wobec cudzoziemców, którzy nie są przybyszami z krajów bogatych, wskazuje na istnienie ograniczeń w tym zakresie. Głównym czynnikiem wpływającym na postawy Polaków wobec cudzoziemców jest już nie tylko sympatia dla danego kraju i narodowości, ale także przydatność danego cudzoziemca w Polsce lub osobista znajomość jego kraju pochodzenia.

\section{OTWARTOŚĆ NA PRZYJAZDY CUDZOZIEMCÓW DO POLSKI A UWARUNKOWANIA KULTUROWE}

Otwartość na przyjazdy cudzoziemców do Polski hipoteza kontaktu

Opierając się na klasycznej koncepcji Gordona Allporta zakładającej osłabienie uprzedzeń w wyniku nawiązania bezpośrednich kontaktów z członkami grupy obcej (zob. Bilewicz 2006, s. 63-64), sądziliśmy, że kontakty takie są jednym $z$ ważnych uwarunkowań otwartości Polaków na przyjazdy cudzoziemców do Polski. Jednak ze względu na możliwą różnorodność ewentualnych doświadczeń osobisty kontakt może mieć różne skutki: może rozwijać zarówno postawy akceptacji, jak i odrzucenia. W naszym badaniu pytaliśmy o osobistą znajomość z cudzoziemcem oraz doświadczenia z pracy zagranicą.

Na pytanie: „Czy zna Pan(i) osobiście jakiegoś cudzoziemca mieszkającego w Polsce?” blisko połowa badanych $(46,9 \%)$ odpowiedziała twierdząco, a ponad połowa $(51,4 \%)$ negatywnie (tylko $1,7 \%$ wskazało odpowiedź „trudno powiedzieć”).

Okazało się, że osoby osobiście znające cudzoziemca częściej popierają przyjazdy obcokrajowców do Polski i rzadziej im się sprzeciwiają (tabela 6). Dwie $z$ nich $(66,9 \%)$ nie wyrażało sprzeciwu wobec ich częstszych przyjazdów (z czego 17\% zdecydowanie je popierało), ale jednak w jedna czwarta $(24,8 \%)$ stanowczo się im przeciwstawiała (a $8,3 \%$ wybierało odpowiedź „trudno powiedzieć”). Z kolei wśród osób deklarujących brak osobistych znajomości z cudzoziemcami ponad połowa $(57,2 \%)$ nie przeciwstawiała się ich przyjazdom (przy czym $6,8 \%$ jednoznacznie je popierała), a ponad jedna trzecia $(37,6 \%)$ im się sprzeciwiała (odpowiedź „trudno powiedzieć" została wybrana przez 5,2\% respondentów). 
Tabela 6

Stosunek do częstszego przyjazdu cudzoziemców do Polski a osobista znajomość z cudzoziemcem w Polsce ( $w$ \%)

\begin{tabular}{|l|c|c|c|}
\hline \multirow{2}{*}{$\begin{array}{c}\text { Stosunek do częstszego przyjazdu } \\
\text { cudzoziemców do Polski }\end{array}$} & \multicolumn{3}{|c|}{ Osobista znajomość z cudzoziemcem w Polsce } \\
\cline { 2 - 4 } & tak & nie & $\begin{array}{c}\text { trudno } \\
\text { powiedzieć }\end{array}$ \\
\hline Tak, chciałbym & 17,0 & 6,8 & 6,0 \\
Jest mi to obojętne & 49,9 & 50,4 & 41,0 \\
Nie chciałbym & 24,8 & 37,6 & 12,0 \\
Trudno powiedzieć & 8,3 & 5,2 & 41,0 \\
\hline
\end{tabular}

Źródło: opracowanie własne.

W świetle naszych wyników bezpośredni kontakt z cudzoziemcami może rodzić dwojakie skutki: prowadzić do postaw akceptacji bądź przeciwnie - do odrzucenia przyjmowania migratów. Może więc albo rozwijać (nasilać) postawy otwartości lub przeciwnie — zamkniętości. Jednak brak osobistej znajomości z cudzoziemcem zdecydowanie sprzyja postawom zamkniętości.

Innym sposobem sprawdzenia hipotezy kontaktu było wzięcie pod uwagę doświadczenia emigracji zarobkowej, które deklarowała jedna piąta badanych $(19,9 \%)$. Można było je interpretować jako czynnik odpowiedzialny za nastawienia wobec otwartości naszego kraju na imigrację.

Tabela 7

Stosunek do częstszego przyjazdu cudzoziemców do Polski a doświadczenia pracy zarobkowej poza granicami Polski (w \%)

\begin{tabular}{|l|c|c|}
\hline \multicolumn{1}{|c|}{$\begin{array}{c}\text { Stosunek do częstszego przyjazdu } \\
\text { cudzoziemców do Polski }\end{array}$} & \multicolumn{2}{c|}{ Praca zarobkowa za granicami Polski } \\
\cline { 2 - 3 } & tak & nie \\
\hline Tak, chciałbym & 15,5 & 10,6 \\
Jest mi to obojętne & 47,5 & 50,4 \\
Nie chciałbym & 26,0 & 32,6 \\
Trudno powiedzieć & 11,0 & 6,4 \\
\hline
\end{tabular}

Źródło: opracowanie własne.

Doświadczenie pracy poza granicami Polski, podobnie jakznajomość cudzoziemca na terenie Polski, pozostaje w związkach statystycznych ze stosunkiem do migracji. Osoby o takich doświadczeniach częściej po- 
pierały przyjazdy imigrantów oraz rzadziej im się sprzeciwiały. Wśród osób z doświadczeniami pracy za granicą 15,5\% zdecydowanie popierało przyjazdy cudzoziemców, a wśród osób bez doświadczeń migracyjnych $10,6 \%$ - różnica jest niewielka, lecz znacząca. W obu przypadkach blisko dwie trzecie respondentów przychylnie patrzy na przyjazdy cudzoziemców (63\% i $61 \%$, czyli różnica mieści się w granicach błędu statystycznego), Kategorią różnicującą postawy respondentów jest odpowiedź „nie chciał(a)bym". Osoby, które nie wyjeżdżały w celach zarobkowych, częściej wyrażają swój sprzeciw $(32,6 \%)$ w porównaniu z osobami mającymi takie doświadczenia (26\%). Można więc powiedzieć, że praca za granicą w pewnej mierze sprzyja otwartości, która wyraża się przede wszystkim w rzadszym odrzucaniu odpowiedzi sprzeciwiającej się przyjazdom cudzoziemców. Podobnie osoby nie wyjeżdżające w celach zarobkowych stosunkowo rzadziej odpowiadają „trudno powiedzieć” $(6,4 \%)$ w porównaniu z tymi badanymi, które mają takie doświadczenia (11\%).

Można więc powiedzieć, że opinie i postawy dotyczące otwartości wobec migracji do Polski w stosunkowo słabo wiążą się z własnymi doświadczeniami emigracyjnymi osób badanych i ich rodzin. Podobne wyniki otrzymano także $\mathrm{w}$ innym badaniu przeprowadzonym prawie $\mathrm{w}$ tym samym czasie (Konieczna-Sałamatin 2019, s. 68).

Otwartość na przyjazdy cudzoziemców do Polski a przekonania światopoglądowe o pożądanym kształcie zróżnicowania kulturowego

Obok związku kontaktu i posiadania doświadczeń z osobistej znajomości z cudzoziemcami z otwartością na ich przyjmowanie do Polski zauważalny jest związek między deklarowaną otwartością na przyjazdy cudzoziemców a przekonaniami badanych co do ich roli w naszym społeczeństwie. Poglądy w tych kwestiach i związane $z$ nimi postawy z pewnością są częścią generalnych wyborów światopoglądowych, takich jak: nastawienie na akceptację odmienności, inkluzywizm, tolerancja, postęp i wielokulturowość, a $z$ drugiej strony - koncentracja na spójności narodowej, wartości tradycji i specyfiki kulturowej, konserwatywne przywiązanie do rodzimej kultury dopuszczające pewną izolację. Stosunek do otwartości państwa polskiego na migrcje może być nie tylko przejawen zwykłej niechęci lub sprzeciwu wobec przyjazdów obcokrajowców, lecz także konsekwencją świadomie wyznawanych poglądów, ugruntowanych opinii o pożądanym kształcie naszego społeczeństwa w dzisiejszym globalnym i zróżnicowanym kulturowo świecie. Wyrazem takich postaw jest 
między innymi postrzeganie przyjazdów cudzoziemców z perspektywy możliwych zagrożeń, co już wcześniej omawialiśmy.

Związek między stosunkiem do otwartości wobec częstszych przyjazdów cudzoziemców a obawami o zagrożenia płynące $z$ takich kontaktów jest widoczny (tabela 8). Logiczne jest, że największą chęcią do przyjmowania w Polsce większej liczby cudzoziemców wykazała się grupa badanych, którzy zarazem nie zauważali żadnego zagrożenia ze strony obcokrajowców - 86,7\% badanych nieczujących zagrożenia nie miałoby nic przeciwko nim, a 17,9\% wręcz popierałoby takie przyjazdy. Ta grupa respondentów wyróżnia się także stosunkowo najrzadziej wyrażanym sprzeciwem wobec imigracji $(9,4 \%$ wypowiedzi) oraz raczej rzadkimi odpowiedziami „trudno powiedzieć $(3,8 \%)$. Badani postrzegający zagrożenia częściej wyrażali zdecydowany sprzeciw wobec imigracji $(56,6 \%)$ oraz niskie dla niej poparcie $(7,7 \%)$, a odsetek odpowiedzi „trudno powiedzieć” wyniósł 7,4\%. Ostatnia grupa - respondenci, którzy nie udzielili jednoznacznej odpowiedzi na pytanie dotyczące ewentualnych zagrożeń ze strony imigrantów - zaskakuje stosunkowo wysokim odsetkiem osób niesprzeciwiających się przyjazdom cudzoziemców $(65,4 \%)$, odsetek osób przeciwnych wyniósł tu 23,4\% (osób niezdecydowanych było 11,2\%).

Tabela 8

Stosunek do przyjazdu cudzoziemców do Polski a opinie o tym, czy ich przyjazdy stanowią zagrożenie (w \%)

\begin{tabular}{|l|c|c|c|}
\hline \multirow{2}{*}{$\begin{array}{c}\text { Stosunek do częstszego przyjazdu } \\
\text { cudzoziemców do Polski }\end{array}$} & \multicolumn{3}{|c|}{ Obecność cudzoziemców w Polsce może powodować } \\
\cline { 2 - 4 } coś złego \\
\hline Tak, chciałbym & tak & nie & $\begin{array}{c}\text { trudno } \\
\text { powiedzieć }\end{array}$ \\
Jest mi to obojętne & 7,7 & 17,9 & 9,1 \\
Nie chciałbym & 28,3 & 68,8 & 56,3 \\
Trudno powiedzieć & 56,6 & 9,4 & 23,4 \\
& 7,4 & 3,8 & 11,2 \\
\hline
\end{tabular}

Źródło: opracowanie własne .

Zadaliśmy również pytanie o to, czy wszystkie narody mają prawo żyć według swoich obyczajów. Blisko dwie trzecie respondentów $(62,3 \%)$ odpowiedziało na nie twierdząco (w tym $17,2 \%$,zdecydowanie tak", a $45,1 \%$ „raczej tak”, a ponad jedna czwarta $(27,2 \%)$, przecząco (w tym raczej nie - 17,7\%, a $9,5 \%$ zdecydowanie nie), a co dziesiąty badany nie miał zdania $(10,5 \%)$. Trzeba zaznaczyć, że nie sugerowaliśmy w tym pytaniu, że 
kraje te miałyby jakiekolwiek kontakty ze społeczeństwem polskim. Odpowiedzi te świadczą o znacznej skali tolerancji kulturowej naszych badanych (jednak wyraźnie mniejszej niż w latach 1988 i 1998) oraz o widocznym podziale społeczeństwa polskiego w zakresie tych przekonań.

Tabela 9

Stosunek do częstszego przyjazdu cudzoziemców do Polski a opinie o tym, czy wszystkie narody mają prawo żyć według swoich obyczajów, nawet jeśli są one dla nas gorszące lub niemoralne, jak np. wielożeństwo? (w \%)

\begin{tabular}{|l|c|c|}
\hline \multirow{2}{*}{$\begin{array}{c}\text { Stosunek do częstszego przyjazdu } \\
\text { cudzoziemców do Polski }\end{array}$} & \multicolumn{2}{|c|}{$\begin{array}{c}\text { Wszystkie narody mają prawo żyć według } \\
\text { własnych obyczajów, nawet jeśli są one dla nas } \\
\text { gorszące lub niemoralne, jak np. wielożeństwo }\end{array}$} \\
\cline { 2 - 3 } & tak & nie \\
\hline Tak, chciałbym & 13,9 & 8,1 \\
Jest mi to obojętne & 55,8 & 37,0 \\
Nie chciałbym & 24,3 & 59,8 \\
Trudno powiedzieć & 6,1 & 5,1 \\
\hline
\end{tabular}

Źródło: opracowanie własne.

Ujawnione postawy miały związek statystyczny ze stosunkiem do otwartości na przyjmowanie do Polski migrantów, gdyż respondenci, którzy odpowiadali twierdząco na pytanie o prawo do życia według własnych obyczajów, rzadziej się sprzeciwiali przyjazdom cudzoziemców, ci zaś, którzy odpowiadali przecząco, częściej byli im przeciwni (tabela 9). Pojawia się więc pewna spójność poglądów. Wśród osób odpowiadających twierdząco na to pytanie około $70 \%(69,7 \%)$ nie wyrażało sprzeciwu wobec częstszych przyjazdów obcokrajowców, a jawny sprzeciw wyraził blisko co czwarty badany $(24,3 \%)$. Natomiast wśród nieakceptujących odmienności obyczajowej blisko co drugi badany deklarował także niechęć wobec przyjazdów cudzoziemców $(49,8 \%)$, postawę obojętną wyraziło 37,0\%, a poparcie $8,1 \%$. Możliwym uzasadnieniem takiego związku statystycznego jest to, że deklarowana akceptacja imigracji do Polski może być wynikiem niedostrzegania ewentualnych indywidualnych lub kolektywnych konsekwencji, jak choćby postępujący pluralizm religijny (w przypadku zwiększenia liczby przyjazdów osiedleńczych postawy te mogłyby ulec zasadniczej zmianie).

$\mathrm{Na}$ koniec naszej wstępnej analizy zwróćmy jeszcze uwagę na odpowiedzi na pytanie dotyczące otwartości kulturowej, które brzmiało „Czy uważa Pan(i), że ludzie różnych ras i narodów mogą żyć zgodnie w jednym 
kraju?" (zakładaliśmy, że wskazane w pytaniu różne rasy i narody kojarzą się z rozmaitością kulturową). Twierdząco odpowiedziało na nie blisko dwie trzecie badanych $(65,0 \%$, w tym „zdecydowanie tak” $-15,1 \%$ i „raczej tak" 49,9\%), przeczącej odpowiedzi udzieliło około jednej czwartej badanych (23,8\%; w tym „raczej nie” 19,2\% i „zdecydowanie nie” 4,6\%), a odpowiedź „trudno powiedzieć” wybrał co dziesiąty badany (11,2\%).

Tabela 10

Stosunek do częstszego przyjazdu cudzoziemców do Polski a poglądy na temat czy ludzie różnych ras i narodów mogą żyć zgodnie w jednym kraju? (w \%)

\begin{tabular}{|l|c|c|}
\hline \multirow{2}{*}{$\begin{array}{c}\text { Stosunek do częstszego przyjazdu } \\
\text { cudzoziemców do Polski }\end{array}$} & \multicolumn{2}{|c|}{$\begin{array}{c}\text { Ludzie różnych ras i narodów mogą żyć } \\
\text { zgodnie w jednym kraju }\end{array}$} \\
\cline { 2 - 3 } & tak & nie \\
\hline Tak, chciałbym & 15,3 & 5,0 \\
Jest mi to obojętne & 59,9 & 25,9 \\
Nie chciałbym & 18,4 & 64,0 \\
Trudno powiedzieć & 6,4 & 5,0 \\
\hline
\end{tabular}

Źródło: opracowanie własne.

Wśród grupy respondentów twierdzących, że ludzie mogą żyć w zgodzie bez względu na ich pochodzenie narodowe i rasowe blisko trzy czwarte $(73,2 \%)$ nie przeciwstawiałoby się częstszym przyjazdom cudzoziemców, prawie co piąty $(18,4 \%)$ nie wyraziłby na nie zgody, a $6,4 \%$ odpowiedziało „trudno powiedzieć”. W grupie badanych wyrażających opinię przeciwną, tj., że nie możliwe jest zgodne współżycie ludzie o różnym pochodzeniu prawie dwie trzecie $(64,0 \%)$ nie chciałoby takich przyjazdów, co dwudziesty wyrażałby taką chęć (5\% udzieliło odpowiedzi „trudno powiedzieć").

\section{PODSUMOWANIE}

W 2018 roku - w porównaniu z deklarowanymi odpowiedziami respondentów z lat 1988 i 1998 - zauważalny jest wyraźny spadek postaw otwartości na częstsze przyjazdy cudzoziemców do Polski oraz wzrost udziału osób wyraźnie im przeciwnych. Wpływ na obecne nastawienia badanych mogły mieć z jednej strony ich osobiste doświadczenia, które na przestrzeni lat zaczęły przybierać formę rzeczywistej (nieabstrakcyjnej) styczności z cudzoziemcami - imigrantami, a z drugiej strony silne oddziaływanie dyskursu medialnego, w którym nadal obecny jest kryzy- 
su migracyjnego zapoczątkowany w 2015 roku. Możemy też zauważyć, że otwarte, inkluzywistyczne postawy wobec kontaktów z cudzoziemcami, wyrażone w postaci popierania częstszych przyjazdów do naszego kraju cudzoziemców, nie są tylko prostymi nastawieniami wrogimi lub przychylnymi (tak lub nie), lecz wiążą się z szerszymi kompleksami światopoglądowymi opisującymi kształt społeczeństwa, które obecnie doświadcza skutków procesów imigracji.

Przyglądając się danym porównawczym z perspektywy zróżnicowania społeczno-demograficznego respondentów, można dostrzec, że na szczególną uwagę zasługują takie zmienne, jak wykształcenie oraz praktyki religijne, gdyż istnieje związek statystyczny między tymi zmiennymi a analizowanymi postawami. Zwróćmy uwagę, że ten związek religijności (religijności kościelnej) z postawami wobec cudzoziemców, a zwłaszcza skłonność do postrzegania ich niekorzystnego wpływu na nasze społeczeństwo, wiąże się zarówno $z$ obawami o bezpieczeństwo własne (konkretne zagrożenie ładu społecznego), jak i troską o zachowanie ładu symbolicznego w naszym kraju (zagrożenie symboliczne) (Konieczna 2019, s. 70-71). Ważnym czynnikiem różnicującym postawy wobec przyjmowania uchodźców stały się poglądy polityczne respondentów, które w poprzednich edycjach badania nie miały znaczenia. Bardziej przychylne opinie o otwartości kraju formułowali przedstawiciele partii lewicowych (zwłaszcza potencjalni wyborcy Partii Razem) oraz zwolennicy partii Nowoczesna. Bardziej nieprzychylne nastawienia stały się widoczne wśród elektoratu partii prawicowych, wśród których wyróżniali się zwolennicy Prawa i Sprawiedliwości i ówczesnego ugrupowania Kukiz '15. Pod tym względem bardzo podobne wyniki otrzymano w sondażach CBOS, dotyczących postaw wobec uchodźców i ich przyjmowania w naszym kraju w ramach programu relokacji (CBOS 2017; CBOS 2018b).

Podkreślić należy, że względnie słaby okazał się związek statystyczny między opiniami badanych w kwestii częstszych przyjazdów cudzoziemców a ogólnie rozumianym doświadczeniem wyjazdów za granicę do pracy oraz osobistą znajomością z obcokrajowcami. W odpowiedzi na pytanie, kto w naszym kraju jest najbardziej gotowy na częstsze przyjazdy cudzoziemców, należy wskazać osoby dobrze wykształcone (czyli w założeniu posiadające większą od innych wiedzę i ambicje poznawcze), o stabilnym zatrudnieniu (czyli nie zagrożone materialnie), o niezaangażowanym stosunku do wiary (czyli mniej zorientowane na wartości tradycyjne). To oni częściej niż pozostali respondenci wykazywali otwarte postawy wobec potencjalnie częstszych przyjazdów obcokrajowców do Polski. Dodajmy, że pewne uwarunkowania społeczne nieczynne i niewi- 
doczne w poprzednich edycjach badań w 2018 roku ożyły, nabrały treści i wyraźnie zaczęły określać wybory badanych. W reakcjach naszych badanych znajduje odzwierciedlenie całościowy kompleks szerszych zmian społeczeństwa polskiego, jego podziałów społecznych oraz wartości kulturowych. Stosunek do akceptacji migrantów w różnych rolach to nie tylko proste wyrażenie chęci lub zakazu takich przyjazdów, lecz motywowany w sposób świadomy kompleks opinii na cały zespół powiązanych tematów. Postawy poparcia i sprzeciwu lub inaczej postawy otwartości i zamknięcia są związane z określonymi światopoglądowymi opiniami dotyczącymi uznawania różnorodności kulturowej i spójności porządku społecznego.

\section{BIBLIOGRAFIA}

Andrejuk Katarzyna, 2017, Znaczenie polskiej sfery welfare dla imigrantów. Opinie i praktyki ludności naptywowej $z$ wybranych krajów europejskich, „Studia BAS”, nr 2 (50), s. 107-128 .

Andrejuk Katarzyna, 2015, Postawy wobec imigrantów w świetle wyników Europejskiego Sondażu Społecznego 2014-2015. Polska na tle Europy, European Studies Unit, Polish Academy of Sciences Institute of Philosophy and Sociology, Warsaw, „Working Paper”, nr 2, s. 1$-23$.

Bauman Zygmunt, 2016, Obcy u naszych drzwi, Wydawnictwo Naukowe PWN, Warszawa.

Bielecka-Prus Joanna, 2018, Retoryka lęku przed obcym w polskim dyskursie prasowym, „Colloquium Wydziału Nauk Humanistycznych i Społecznych. Kwartalnik”, nr 1, s. 5-34.

Bilewicz Michał, 2006, Kiedy kontakt osłabia uprzedzenia? Kategoryzacje spoteczne i temporalne jako warunki skuteczności kontaktu międzygrupowego, „Psychologia Społeczna”, nr 2(2), s. 63-74.

CBOS, 2015, Przybysze z bliska i z daleka, czyli o imigrantach $w$ Polsce. Komunikat z badań, nr 93, Centrum Badania Opinii Społecznej, Warszawa, czerwiec.

CBOS, 2017, Stosunek Polaków do przyjmowania uchodźców. Komunikat z badań, nr 1, Centrum Badania Opinii Społecznej, Warszawa, styczeń.

CBOS, 2018a, Stosunek do innych narodów. Komunikat z badań, nr 37, Centrum Badania Opinii Społecznej, Warszawa, marzec.

CBOS, 2018b, Stosunek Polaków i Czechów do przyjmowania uchodźców. Komunikat z badań, nr 87, Centrum Badania Opinii Społecznej, Warszawa, lipiec.

Cieśla Joanna, 2016, Obcy wyjęci z sieci, „Polityka”, 26 października-1 listopada.

Croucher Stephen M., 2016, Integrated Threat Theory, „Oxford Research Encyclopedia of Communication”, University Press USA, Oxford, s. 1-15.

Garapich Michał P., 2019, Migracje z Polski do Wielkiej Brytanii: geneza, stan dzisiejszy, wyzwania na przyszłość, „Studia BAS”, nr 4 (60), s. 13-30.

Górny Agata, Kindler Marta, 2018, Cudzoziemcy w Polsce na przełomie XX i XXI wieku, w: Magdalena Lesińska, Marek Okólski (red.), 25 wykładów o migracjach, Scholar, Warszawa, s. 235-248. 
Grzymała-Kazłowska Aleksandra, 2012, Paradoksy polskiej tolerancji. Postawy wobec mniejszości i imigrantów w Polsce na tle Europy, w: Aleksandra Jasińska-Kania (red.), Wartości i zmiany. Przemiany postaw Polaków w jednoczącej się Europie, Scholar, Warszawa, s. 131-164.

Hall Dorota, Mikulska-Jolles Agnieszka, 2016, Uprzedzenia, strach czy niewiedza? Młodzi Polacy o powodach niechęci do przyjmowania uchodźców, Stowarzyszenie Interwencji Prawnej, Warszawa.

Jaroszewicz Marta, 2018, Migracje z Ukrainy do Polski — Stabilizacja trendu. Raport OSW, Ośrodek Studiów Wschodnich, Warszawa.

Jaskułowski Krzysztof, 2019, The Everyday Politics of Migration Crisis in Poland: Between Nationalism, Fear and Empathy, Palgrave Macmillan, Cham, Switzerland.

Społeczne skutki..., 2014, Społeczne skutki poakcesyjnych migracji ludności Polski, Polska Akademia Nauk, Komitet Badań nad Migracjami PAN, Warszawa.

Konieczna-Sałamatin Joanna, 2019, Konkurencja, zagrożenie czy ratunek dla gospodarki? Postawy Polaków wobec imigrantów, „Studia Socjologiczno Polityczne. Seria Nowa”, nr 1 (10), s. 61 $-82$.

Migranci, uchodźcy..., 2018, Migranci, uchodźcy i ksenofobia w kampanii wyborczej 2018 - raport z monitoringu, Helsińska Fundacja Praw Człowieka, Warszawa, s. 1-35.

Nowicka Ewa (red.), 1990, Swoi i obcy, Instytut Socjologii UW, Warszawa.

Nowicka Ewa, 2011, Badanie rasizmu: problemy metodologiczne, „Studia Migracyjne. Przegląd Polonijny", nr 4 (142), s. 121-144.

Nowicka Ewa, Łodziński Sławomir, 2001, U progu otwartego świata. Poczucie polskości i nastawienia Polaków wobec cudzoziemców w latach 1988-1998, Nomos, Kraków.

OECD, 2019, International Migration Outlook 2019, OECD Publishing, Paris (https://www.oec d.org/migration/international-migration-outlook-1999124x.htm [dostęp: 17.05.2020]).

Organiściak-Krzykowska Anna, 2018, Konsekwencje społeczno-ekonomiczne sytuacji demograficznej w Polsce, w: Józefina Hrynkiewicz, Janusz Witkowski, Alina Potrykowska (red.), Sytuacja demograficzna Polski jako wyzwanie dla polityki społecznej i gospodarczej, Rządowa Rada Ludnościowa, Warszawa, s. 130-144.

Pasamonik Barbara, Markowska-Manista Urszula (red.), 2017, Kryzys migracyjny. Perspektywa społeczno-kulturowa, t. 1, Wydawnictwo Akademii Pedagogiki Specjalnej, Warszawa.

Pędziwiatr Konrad, 2015, Islamofobia jako nowy wymiar lęków i obaw Polaków, w: Robert Kusek, Jacek Purchla, Joanna Sanetra-Szeliga (red.), Narody i stereotypy 25 lat później, Międzynarodowe Centrum Kultury, Kraków.

Switat Mustafa, 2018, Rasizm i mechanizmy mu pokrewne w kontekście badań nad diaspora arabska w Polsce, „Studia Migracyjne - Przegląd Polonijny, nr 1 (167), s. 189-218.

Taras Raymond, 2019, Re-imaging Nationhood: Consolidating Nativist and Immigrant Social Bonding, „Studia Socjologiczno-Polityczne. Seria Nowa”, nr 1 (10), s. 13-30.

Wark Colin, Galliher John F., 2007, Emory Bogardus and the Origins of the Social Distance Scale, „The American Sociologist”, t. 38(4), s. 383-395.

Winiarska Aleksandra, Wojno Magdalena, 2018, Local Perspective on the Practices and Challenges of Migrant Integration: The Case of Warsaw, „Croatian and Comparative Public Administration", t. 18(3), s. 341-372.

Zubrzycki Jerzy, 1988, Soldiers and Peasants: The Sociology of Polish Migration, The School of Slavonic and East European Studies-Orbis Book, London. 
SHADES OF FOREIGNNESS:

THE RESULTS OF THE SURVEY “POLES AND OTHERS AFTER 30 YEARS”-

A COMPARATIVE ANALYSIS (1988, 1998, 2018)

Ewa Nowicka (Collegium Civitas), Sławomir Łodziński (Warsaw University)

Abstract

The aim of the article is to analyze selected results of the 2018 survey "Poles and Others after Thirty Years" on attitudes to the arrival of foreigners in Poland and to compare them with the results of analogous studies from 1988 and 1998. The authors suggest that the notion of "foreign" is becoming increasingly definite in the consciousness of Polish society. There is a noticeable decline in openness in regard to more foreigners coming to Poland and an increase in the number of people who are clearly opposed to foreigners. The authors argue that the current attitudes of the respondents could have been influenced, on the one hand, by their personal experiences, which in the last few years have begun to take the form of real (non-abstract) contact with foreigners (immigrants), and on the other hand, by the media discourse related to the migration crisis of 2015. In light of the research, open (inclusive) attitudes toward foreigners can not be reduced to simple yes or no answers but remain related to wider world-outlook complexes reflecting the shape of Polish society, which in recent years has experienced the effects of immigration.

key words: own and foreign, social distance, migration, attitudes to foreigners, Polish societ

słowa kluczowe: swój i obcy, dystans społeczny, migracje, nastawienia wobec cudzoziemców, społeczeństwo polskie 